\title{
BIS-THIOUREA BEARING ARYL AND AMINO ACIDS SIDE CHAINS AND THEIR ANTIBACTERIAL ACTIVITIES
}

\section{Wan Sharifatun Handayani Wan Zullkiplee, ${ }^{1}$ Ainaa Nadiah Abd Halim, ${ }^{1}$ Zainab Ngaini, ${ }^{1}$ Maya Asyikin Mohd Ariff, ${ }^{1}$ and Hasnain Hussain ${ }^{2}$ \\ ${ }^{l}$ Department of Chemistry, Faculty of Resource Science and Technology, Universiti Malaysia Sarawak, Kota Samarahan, Sarawak, Malaysia \\ ${ }^{2}$ Department of Molecular Biology, Faculty of Resource Science and Technology, Universiti Malaysia Sarawak, Kota Samarahan, Sarawak, Malaysia}

\section{GRAPHICAL ABSTRACT}
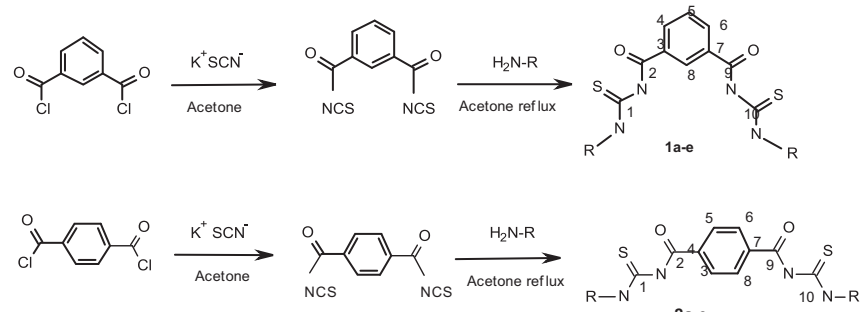

$2 \mathrm{a}-\mathrm{c}$

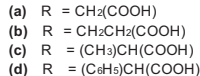

(c) $\mathrm{R}=\left(\mathrm{CH}_{3}\right) \mathrm{CH}(\mathrm{COOH})$

(d) $\mathrm{R}=\left(\mathrm{C}_{6} \mathrm{H}_{5}\right) \mathrm{CH}(\mathrm{COOH})$

(e) $\mathrm{R}=\mathrm{C}_{6} \mathrm{H}_{5}$

Abstract A series of symmetrical 1,3-bis thiourea 1a-e and 1,4-bis thiourea derivatives 2a-e have been successfully synthesized from the reactions of amines with 3-acetylbenzoyl isothiocyanate and 4-acetylbenzoyl isothiocyanate, respectively. All the synthesized compounds were characterized by FT-IR spectroscopy and ${ }^{1} \mathrm{H}$ and ${ }^{13} \mathrm{C}$ NMR spectroscopy. The compounds were screened for their antibacterial activity by turbidimetric method using gram-negative bacteria (E. coli ATCC 8739) using turbidimetric method. The newly synthesized bis-thiourea derivatives bearing aryl side chains showed good antibacterial activity against $\mathrm{E}$. coli. The effect of the molecular structure of the synthesized compounds on the antibacterial activity is discussed.

Keywords Antibacterial activity; amino acid; bis-thiourea

Received 15 December 2012; accepted 12 October 2013.

We thank Assoc. Prof. Dr. Wan Mohd Khairul Wan Mohamed Zin from Universiti Malaysia Terengganu for providing $\mathrm{CHN}$ elemental analysis services.

Address correspondence to Assoc. Prof. Dr. Zainab Ngaini, Faculty of Resource Science and Technology, University Malaysia Sarawak, Chemistry, Unimas, Kota Samarahan, Sarawak, Kuching 94300, Malaysia. E-mail: nzainab@frst.unimas.my 